PEDAGOGIA : Jurnal IImu Pendidikan

\title{
MEDIA KARTU FOTO GROUPFEI BERBASIS TEKNIK AKROSTIK SANDI ASMA DALAM PEMBELAJARAN MENULIS PUISI BERBAHASA JAWA (GEGURITAN)
}

\author{
Romdonah \\ SMP Negeri 1 Weleri Kendal \\ romdonahatmid@gmail.com
}

\begin{abstract}
Abstrak
Pembelajaran menulis puisi berbahasa Jawa(geguritan) merupakan hal yang penting agar siswa mampu mengekspresikan perasaan dan melatih kreativitas serta kepekaan terhadap seni sastra Jawa. Penelitian ini bertujuan mendeskripsikan media Kartu Foto Groupfie berbasis teknik Akrostik Sandi Asma dalam pembelajaran menulis geguritans erta mendeskripsikan dampak positif penerapan Kartu Foto Groupfie berbasis teknik Akrostik Sandi Asma. Metode analisis data yang digunakan adalah analisis kuantitatif dan kualitatif dengan menggunakan instrumen tes untuk memperoleh data kuantitatif serta instrumen non tes untuk memperoleh data kualitatif. Adapun hasil yang dicapai berdasarkan analisis kuantitatif pasca-aplikasi media menunjukkan adanya peningkatan keterampilan menulis geguritan. Pada tahap pra-aplikasi media siswa hanya mencapai nilai rata-rata sebesar 69,38 . Hal tersebut meningkat sebesar $13,14 \%$ pada pasca-aplikasi media tahap I dengan nilai rata-rata sebesar78,50. Masih ada 6 siswa atau 18,75\% yang belum mencapai KKM. Hasil tes pada pasca-aplikasi media tahap II meningkat sebesar 7,81\% dari pasca-aplikasi media tahap I dengan nilai rata-rata klasikal sebesar 84,63. Dari analisis data secara kualitatif diperoleh hasil bahwa sebagian besar siswa tertarik dengan media yang digunakan. Berdasarkan hasil tes dan nontes dapat disimpulkan bahwa media Kartu Foto Groupfie berbasis teknik Akrostik Sandi Asma dapat meningkatkan keterampilan siswa dalam menulis geguritan dan menimbulkan dampak positif terhadap perilaku belajar siswa.
\end{abstract}

Kata Kunci: Media Kartu; Teknik Akrostik; Pembelajaran Menulis Geguritan

\begin{abstract}
Learning to write Javanese poetry (geguritan) is important for students, so that they are able to express feelings, to enhance their creativity, and to sharpen their sensitivity toward Javanese literature. This study aims to describe the Groupfie Photo Card media based on the Asthma Sandi Acrostic Technique in geguritanwriting process and to describe the positive impact of Groupfie Photo Cards application based on Asthma Password Acrostic techniques. The data analysis methodsare quantitative and qualitative analysis methods which use test instruments as the quantitative data as well as non-test instruments as the qualitative data. The results based on quantitative analysis post-media applications indicate an increasing resultsforgeguritan writing skills. At the pre-application stage, students only reach an average score 69.38 . It increased by $13.14 \%$ in the post-media application stage I with an average score 78.50. There are still 6 students or $18.75 \%$ who have not yet reached the minimum standard criteria. The test results on post-media applications stage II increased by $7.81 \%$ from post-media application stage I with a classical average score of 84.63. From the qualitative data analysis, the results showed that most students were interested in the media used. Based on the test and non-test results, it can be concluded that the Groupfie Photo Card media based on the Astrostatic Password
\end{abstract}


PEDAGOGIA : Jurnal IImu Pendidikan

Asthma technique can improve students' skills in writing geguritan and give a positive impact toward student learning behavior.

Keywords: Card Media; Acrostic Technique; Learning to Write Geguritan

\section{A. PENDAhuluaN}

Kesuksesan hidup salah satunya ditentukan oleh pendidikan. Oleh karena itu, peran guru selain mentransfer ilmu pengetahuan kepada siswa, juga memberi bekal ajaran budi pekerti luhur agar menghasilkan generasi yang berilmu dan berkarakter yang mampu menerapkan nilai kemanusiaan dalam hidupnya. Hal ini sejalan dengan kata-kata bijak dari Ki Hajar Dewantara yang menyatakan "Apalah arti kepintaran dan ilmu yang tinggi, jika jauh dari kemasyarakatan dan budaya".

Keberadaan mata pelajaran bahasa Jawa sebagai muatan lokal wajib di Provinsi Jawa Tengah dikandung maksud dapat membekali siswa dengan budi pekerti yang luhur. Salah satu Kompetensi Dasar (KD) yang harus dikuasai siswa yakni mampu menulis geguritan. Pembelajaran menulis geguritan bertujuan agar siswa mampu mengekspresikan perasaan dan pikirannya, menunjukkan kreativitas, dan memiliki kepekaan terhadap seni sastra terutama sastra Jawa.

Berdasarkan observasi awal menunjukkan bahwa menulis geguritan merupakan hal sulit bagi siswa. Hasil pretes menulis geguritan rata-rata nilainya rendah dan belum mencapai Kriteria Ketuntasan Minimal (KKM) sebesar 75. Selain itu, siswa menganggap menulis geguritan merupakan hal sulit, sehingga banyak siswa yang copy paste dari internet saat diberi tugas menulis geguritan. Melihat fenomena tersebut, dalam pembelajaran menulis geguritan diperlukan media dan teknik yang dapat menjadi solusi bagi guru dan siswa untuk mengatasi permasalahan tersebut. Hal tersebut sesuai kajian Utami (2012) yang dimuat dalam Jurnal Portal Kurikulum menunjukkan perlu adannya langkah strategis untuk menjadikan pembelajaran menulis puisi menjadi lebih bermakna bagi siswa, yakni menggunakan teknik agar pembelajaran menjadi lebih menarik.

Selain itu, Mardiah (2013) dalam artikel yang dimuat dalam Jurnal Program Studi Pendidikan Bahasa dan Sastra Indonesia Fakultas Keguruan dan Ilmu Pendidikan Universitas Bung Hatta Padang menyatakan untuk meningkatkan kualitas pembelajaran terutama menulis puisi dapat digunakan berbagai macam media pembelajaran.

Sejalan dengan kedua pendapat tersebut, Monika (2014) dalam artikel yang dimuat dalam Jurnal Jurusan Pendidikan Dasar Fakultas Keguruan dan Ilmu Pendidikan Universitas Tanjungpura Pontianak menyatakan agar siswa mengenal dan menyentuh objek secara dekat dalam pembelajaran menulis puisi 
PEDAGOGIA : Jurnal Ilmu Pendidikan

seorang pendidik harus menyiapkan alternatif lain yang sesuai dengan kondisi siswa dan lingkungan, agar pembelajaran tetap berlangsung efektif dan efisien.

Berdasarkan latar belakang, maka rumusan masalah dalam penelitian ini (1) bagaimanakah media Kartu Foto Groupfie berbasis teknik Akrostik Sandi Asma dalam pembelajaran menulis geguritan? dan (2) bagaimanakah dampak positif penerapan media Kartu Foto Groupfie berbasisteknik Akrostik Sandi Asmadalam pembelajaran menulis geguritan terhadap perilaku belajar siswa? Oleh karena itu, penelitian ini bertujuan (1) mendiskripsikan media Kartu Foto Groupfie berbasis teknik Akrostik Sandi Asma dalam pembelajaran menulis geguritan, dan (2) mendeskripsikan dampak positif penerapan media Kartu Foto Groupfie berbasis teknik Akrostik Sandi Asma dalam pembelajaran menulis geguritan terhadap perilaku belajar siswa.

\section{B. TINJAUAN PUSTAKA}

Hasil penelitian yang relevan yang menjadi dasar penelitian ini adalah penelitian Andrina (2011), Sari (2014), dan Sudarwati (2015). Tahun 2011 Andrina dalam penelitian dengan judul "Peningkatan Kemampuan Menulis Puisi dengan Media Kartu Mimpi Bergambar pada Siswa Kelas VIII SMP Negeri 8 Magelang" memaparkan bahwa pembelajaran menulis puisi dengan menggunakan media Kartu Mimpi Bergambar mampu meningkatkan kemampuan siswa dalam menulis puisi. Kelebihan penelitian ini adalah penggunaan media Kartu Mimpi Bergambar mampu merangsang imajinasi siswa dalam menulis puisi. Adapun kelemahannya guru harus lebih kreatif dan jeli dalam menyiapkan gambar benarbenar cocok dan mendidik yang akan digunakan sebagai media pembelajaran.

Sari (2014) dalam penelitian dengan judul "Peningkatan Kualitas Pembelajaran Menulis Puisi dengan Metode Field Trip pada Siswa SMP" menjelaskan bahwa penerapan metode field trip dapat meningkatkan kualitas proses dan hasil menulis puisi siswa dan meningkatkan motivasi serta keaktifan siswa dalam menulis puisi. Kelebihan dari penelitian ini adalah metode field trip sangat sesuai untuk meningkatkan pembelajaran menulis puisi karena dengan melihat objek secara langsung di luar kelas, siswa dapat termotivasi dalam mengikuti pembelajaran yang cenderung tidak membosankan serta siswa dapat dengan mudah menuangkan ide atau gagasannya ke dalam puisi. Adapun kelemahan dari penelitian ini adalah manajemen waktu harus dipercermati mengingat jam tatap muka mata pelajran bahasa Jawa hanya dua jam pelajaran tiap minggunya. Oleh karena itu, perlu dicari solusinya dengan menggunakan jam di luar jam pelajaran sesuai kesepakatan antara guru dengan siswa. 
PEDAGOGIA : Jurnal Ilmu Pendidikan

Tahun 2015 Sudarwati melakukan penelitian dengan judul "Peningkatan Hasil Belajar Menulis Cerkak dengan Media Foto SMSHP, dari hasil penelitian tersebut terbukti media SMSHP dapat membantu siswa dalam menulis cerkak. Kelebihan penelitian tersebut adalah media yang digunakan dalam pembelajaran mampu menciptakan proses belajar mengajar bahasa Jawa menjadi efektif dan hasil belajar siswa menjadi optimal. Adapun kelemahannya adalah belum diterapkan teknik yang mendukung penerapan media, sehingga akan mengoptimalkan siswa dalam menulis puisi atau cerkak.

Penelitian ini merupakan pengembangan dari penelitian tentang penggunaan teknik field trip, media kartu mimpi bergambar, dan media foto dalam ketiga penelitian tersebut. Media kartu foto dalam penelitian ini merupakan pengembangan kartu mimpi bergambar penelitian Andrina. Adapun media SMSHP untuk menulis cerkak (cerpen) dari penelitian Sudarwati dikembangkan menjadi media untuk menulis geguritan (puisi). Dari teknik field trip selanjutnya dikembangkan menjadi teknik akrostik sandi asma untuk mempermudah siswa dalam menulis geguritan.

\section{Media Kartu Foto Groupfie}

Media ini merupakan salah satu media yang menggabungkan antara kartu dan foto groupfie. Daryanto (2011) menjelaskan bahwa media foto dalam pembelajaran sangat efektif untuk dijadikan media visual yang dapat merangsang kreativitas imajinasi siswa. Sadiman dalam Musfiqon (2012) yang menyatakan bahwa sebuah gambar atau foto akan lebih banyak berbicara daripada seribu kata yang diungkapkan secara lisan.

Istilah foto groupfie adalah pengembangan dari istilah foto selfie yang merupakan akronim dari istilah group dan selfie yang kurang lebih berarti sekelompok orang yang mengambil foto selfie. Adib (2016) menjelaskan bahwa kata groupfie tidak sepopuler selfie. Untuk memperjelas gambaran tentang perbedaan tata cara orang melakukan foto selfei dengan foto groupfie dapat dilihat dalam gambar 1 berikut ini.
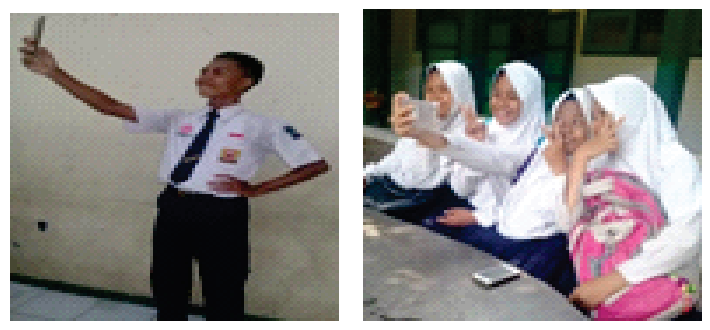

\section{Gambar 1}

Perbedaaan Foto Selfie dan Groupfie

Media Kartu Foto Groupfie bentuknya kertas segi empat yang berisi foto hasil groupfie pada sisi pertama dan deskripsi pada sisi kedua. Deskripsi dalam kartu tersebut berupa catatan yang berhubungan dengan gambar yang diharapkan akan memunculkan imajinasi siswa yang dapat dijadikan unsur-unsur pembangun geguritan. 
PEDAGOGIA : Jurnal Ilmu Pendidikan

\section{TeknikAkrostikSandiAsma}

Ada beberapa teknik untuk mempermudah seseorang yang berlatih menulis geguritan, salah satunya teknik akrostik. Sudibyo (2008) memaparkan bahwa kata akrostik berasal dari bahasa Perancis acrostiche dan bahasa Yunani akrostichis yang artinya beberapa kata yang disusun huruf awalnya berupa barisbarisnya menjadi sebuah sajak. Utami (2015) menjelaskan bahwa teknik yang paling jitu menulis puisi bagi penulis pemula adalah teknik akrostik. Cara yang dapat dilakukan dengan memanfaatkan huruf pertama tiap kata yang dijadikan tema atau judul untuk memulai menulis tiap-tiap baris puisi. Berdasarkan kedua pendapat tersebut dapat disimpulkan bahwa teknik akrostik merupakan cara menulis puisi dengan langkah (1) menentukan tema atau judul, (2) menuliskan kata yang berhubungan dengan judul secara vertikal ke bawah yang akan membentuk huruf yang mengawali setiap baris puisi, dan (3) melanjutkan huruf yang telah disusun menjadi kata atau yang indah.

Sandi asma dalam bahasa Jawa sebenarnya sama dengan akrostik dalam penulisan puisi. Sandi asma adalah nama yang dirahasiakan (sinandi) atau disembunyikan. Penggunaan sandi asma dengan cara nama pengarang tembang dipisah-pisah suku kata atau hurufnya dan dimasukkan dalam baris syair tembang atau geguritan. Gugun 7 (2011) menjelaskan dalam menulis geguritan dapat menggunakan huruf pertama, huruf tengah, huruf terakhir yang ada dalam kata atau nama. Setiap kata harus terjaga koherensinya dan memiliki arti. Sandi asma yang terletak di depan merupakan sandi asma yang paling mudah dipraktikkan. Rahayu (2015) menjelaskan bahwa susunankata dan bahasa dalam geguritan dapat menghasilkan unsur estetika dalam bentuk sandi asma. Berikut contoh penempatan sandi asma dalam sebuah geguritan karangan seorang penyair bahasa Jawa terkenal yakni Ani Asmara.

Aku ini dudu ahli sastra lan pujangga

Nanging mung tukang dongeng gawe crita

Ing pangajab melu memetri basa Jawa

Awit iku basa tetilare leluhur kita

Sing pantes diurip-urip amrih ra sirna

Marga moncering bangsa ora pisah karo basa

Amula wajib kitab pepetri amrih kuncara

Rawe-rawe rantas malang-malang dakdhadha

Ani Asmara tetep marsudi basa Jawa.

\section{Pembelajaran Menulis Geguritan}

Isdisusilo (2012) menyatakan hakikat pembelajaran adalah kegiatan bertujuan memberikan pengalaman belajar kepada siswa. Komalasari (2013) mendefinisikan pembelajaran adalah suatu sistem dalam membelajarkan siswa yang direncanakan atau didesain, dilaksanakan, dan dievaluasi secara sistematis untuk mencapai tujuan pembelajaran secara efektif dan efisien. Hakikat menulis 
PEDAGOGIA : Jurnal Ilmu Pendidikan

menurut Kurniawan dan Sutardi (2012) adalah kegiatan mengungkapkan ide, gagasan, pikiran, dan perasaan dalam bentuk bahasa secara tertulis. Kosasih (2014) menyatakan bahwa salah satu keterampilan yang sangat penting bagi seseorang adalah keterampilan menulis, karena dapat dijadikan bekal hidup.

Geguritan adalah puisi berbahasa Jawa. Mulyana (2014) berpendapat bahwa puisi Jawa merupakan karya sastra yang bebas aturan dan memiliki lisencia poetica serta lisencia gramatica yakni kebebasan berbahasa, kebebasan memilih kata, dan kebebasan mengungkapkan makna serta pesan. Rakhmawati (2015) menjelaskan bahwa geguritan adalah karya sastra yang memiliki unsur pembentuk yang sistematis, mengandung makna konotatif dan denotatif, serta memiliki keindahan dalam setiap katakatanya.

Ada beberapa tahapan dalam menulis geguritan. Kurniawan dan Sutardi (2012) menyatakan ada empat tahapan proses kreatif menulis puisi (geguritan), yakni (1) menggali ide, (2) merenungkan atau mengendapkan ide, (3) menulis, (4) mengedit dan merevisi. Dalam menulis geguritan sangat diperlukan kreativitas yang tidak langsung muncul, namun banyak hal yang mempengaruhinya. Salah satu hal yang dapat mempengaruhi adalah suasana pembelajaran yang menyenangkan. Sufanti (2010) menyatakan bahwa pembelajaran dalam suasana yang meriah, riang, gembira, nyaman membuat siswa betah belajar, serta tidak dalam suasana yang menakutkan atau tertekan merupakan pembelajaran yang sangat diharapkan siswa.

\section{METODE PENELITIAN}

Penelitian ini didesain dalam bentuk penelitian pengembangan program media berdasarkan teori dari Arsyad (2011) dengan tahapan sebagai berikut.

1. Penganilisisan Karakteristik Umum Siswa

Secara umum siswa kelas IX SMP merupakan anak dalam tahap pubertas yang memiliki beberapa karakteristik yang menonjol. Hal ini sejalan dengan pendapat Desmita (2014) yang menyatakan bahwa anak usia SMP berada pada tahap perkembangan pubertas yang memiliki ciri yang menonjol di antaranya mulai mencari jati diri dalam dunia sosial. Oleh karena itu, guru harus memberikan ruang dan waktu kepada siswa untuk melakukan kegiatan yang positif yang sesuai dengan hobi dan minat yang dimilikinya. Dengan demikian media ini sangat relevan dengan karakteristik umum siswa SMP.

2. Perumusan Tujuan yang Akan Dicapai dalam Pembelajaran

Sesuai dengan silabus, dalam pembelajaran menulis geguritan ini bertujuan agar siswa mampu menulis geguritan. Perumusan tujuan yang 
PEDAGOGIA : Jurnal Ilmu Pendidikan

akan dicapai dalam pembelajaran disesuaikan dengan Standar Kompetensi, Kompetensi Dasar, dan materi pembelajaran. Hal ini merupakan implementasi teori prinsip keterkaitan dan keterpaduan penyusunan Rencana Pelaksanaan Pembelajaran. Narwanti (2011) menyatakan bahwa dalam penyusunan RPP ada beberapa prinsip yang harus diperhatikan, di antaranya prinsip keterkaitan dan keterpaduan antara $\mathrm{SK}$, KD, dan materi pembelajaran. Oleh karena itu bentuk media ini sudah disesuaikan dengan tujuan pembelajaran yang akan dicapai.

3. Pemilihan, Penyusunan, serta Pengembangan Materi Sesuai dengan Media dan Teknik Pembelajaran yang Digunakan

Pemilihan, penyusunan, dan pengembangan materi pembelajaran pada Kompetensi Dasar (KD) menulis geguritan ini didasarkan pada bahan ajar berbasis cetak. Prastowo (2012) menjelaskan bahwa bahan ajar yang berbasis cetak salah satunya dapat berupa foto. Dalam pemilihan foto telah dipertimbangkan subtansi materi dan relevansi Kompetensi Dasar (KD). Oleh karena itu, dalam media ini pemilihan tema foto telah disesuaikan dengan karakteristik siswa dan perkembangan psikologinya.

4. Pengaplikasian Media
Dalam mengaplikasi media ini telah dipraktikkan siswa secara langsung. Amri dan Ahmadi (2010) menyatakan penerapan PAIKEM (Pembelajaran Aktif, Inovatif, Kreatif, Efektif, Menyenangkan) yang melibatkan siswa merupakan pengembangan kemampuannya yang menekankan kegiatan praktik.

5. Permintaan Tanggapan dari Siswa dan Teman Sejawat

Media yang telah dimintakan tanggapan dari siswa dan teman sejawat dalam forum MGMP tingkat kabupaten. Tujuan permintaan tanggapan ini untuk menentukan apakah media ini dapat dikategorikan efektif atau tidak.

6. Pengevaluasian Proses Pembelajaran Evaluasi aplikasi media ini dimaksudkan agar diketahui apakah media ini mampu meningkatkan kualitas dalam pembelajaran. Mujib (2012) menyatakan pembelajaran tidak lepas dari sebuah penilaian sebagai suatu proses dalam menentukan kualitas hasil belajar siswa dan tingkat pencapaian tujuan dalam pembelajaran.

Analisis data yang digunakan dalam penelitian ini yakni analisis kuantitatif dan kualitatif. Pengambilan data menggunakan teknis tes mendapatkan data secara kuantitatif berupa skor dari hasil tes menulis geguritan yang dihasilkan siswa.Pebngambilan data menggunakan teknis nontes untuk mendapatkan data 
secara kualitatif untuk mengetahui perubahan perilaku belajar siswa setelah digunakan media teresebut.

Mekanisme pemanfaatan media ini dalam pembelajaran sangat mudah. Penerapan media ini telah memunculkan kompetensi unggulan pada kegiatan pembelajaran. Keunggulan tersebut di antaranya mampu membuat siswa aktif sejak dini. Sebelumnya siswa telah diberi tugas di luar jam pelajaran untuk berswafoto dalam bentuk groupfie bersama anggota keluarga dan teman satu kelas. Pada tahap ini penanaman nilai karakter sudah mulai ditanamkan di antaranya saran guru untuk saling membantu dalam pengambilan gambar karena tidak semua siswa memiliki kamera. Selain itu, penanaman rasa bangga terhadap keluarga sendiri. Adapun penerapan teknik Akrostik Sandi Asma memiliki pesan moral bahwa sebuah nama diri yang diberikan oleh orang tua merupakan nama terindah yang merupakan harapan dan doa. Selain itu, melalui teknik Akrostik Sandi Asma merupakan salah satu cara menghindarkan siswa dari plagiasi karya orang lain, karena dengan mengurai nama diri telah menunjukkan keorisinalitasan penulisnya.

\section{HASIL DAN PEMBAHASAN}

Penggunaan media Kartu Foto Groupfie berbasis teknik Akrostik Sandi Asmadalam pembelajaran menulis geguritan ini ternyata mampu menghasilkan (1) peningkatan hasil belajar, dan (2) peningkatan motivasi siswa dalam belajar. Peningkatan hasil belajar pasca-aplikasi media ini sejalan dengan pendapat dari Narwanti (2011) yang menyatakan bahwa siswa akan belajar secara maksimal dan mudah dalam mempelajari materi pembelajaran jika didukung dengan media kreatif. Adapun peningkatan motivasi siswa dalam belajar sesuai dengan pendapat Amri dan Ahmadi (2010) yang memaparkan bahwa sebagai seorang pembelajar siswa harus diberikan rangsangan agar mampu belajar mandiri, karena pada dasarnya manusia mempunyai kecenderungan untuk belajar sesuai dengan minat dan bakat. Berikut dipaparkan hasil aplikasi praktis media pembelajaran tersebut.

\section{Peningkatan Hasil Belajar Siswa}

Hasil tes pra-aplikasi media menunjukkan dari 32 siswa, baru 15 siswa (46,88\%) yang mencapai dan melampui KKM sebesar 75 . Ada 10 siswa (32,25\%) dengan nilai baik. Ada 13 siswa (40,63\%) dengan nilai cukup. Ada 5 siswa $(15,63)$ dengan nilai kurang. Adapun 4 siswa $(12,50 \%)$ dengan nilai sangat kurang. Rata-rata nilai siswa pada tahap praaplikasi sebesar 69,38 dalam kategori kurang dan belum mencapai KKM. Untuk memperjelas analisis hasil tes pra-aplikasi media dapat dilihat dalam tabel 1 berikut ini. 
PEDAGOGIA : Jurnal IImu Pendidikan

Tabel 1

Hasil Tes Pra-aplikasi Media

\begin{tabular}{cccccc}
\hline No. & Kategori & $\begin{array}{c}\text { Rentang } \\
\text { Skor }\end{array}$ & Frekuensi & $\begin{array}{c}\text { Bobot } \\
\text { Skor }\end{array}$ & $\%$ \\
\hline 1 & $\begin{array}{c}\text { Sangat } \\
\text { Baik }\end{array}$ & $90-100$ & 0 & 0 & 0 \\
& & & & \\
\hline 2 & Baik & $80-89$ & 10 & 802 & 31,25 \\
\hline 3 & Cukup & $70-79$ & 13 & 952 & 40,63 \\
\hline 4 & Kurang & $60-69$ & 5 & 314 & 15,63 \\
\hline 5 & Sangat & $=59$ & 4 & 152 & 12,50 \\
& Kurang & & & & \\
\hline \multicolumn{7}{c}{ Jumlah } & & 35 & 2220 & $100 \%$
\end{tabular}

Hasil tes pasca-aplikasi media tahap I menunjukkan siswa secara klasikal mencapai rata-rata nilai 78,50 dan berkategori cukup. Dari 32 siswa, ada 1 siswa $(3,13 \%)$ dengan nilai sangat baik. Ada 14 siswa (43,75\%) dengan nilai baik. Ada 14 siswa $(43,75 \%)$ dengan nilai cukup. Ada 3 siswa (9,37\%) dengan nilai kurang. Ada 0 siswa $(0 \%)$ dengan nilai sangat kurang. Hasil tes pasca-aplikasi media tahap I dapat dipaparkan dalam tabel 2 berikut ini.

\section{Tabel 2}

\begin{tabular}{cccccc}
\multicolumn{6}{c}{ Hasil Tes Pasca-aplikasi Media Tahap I } \\
\hline No. & Kategori & $\begin{array}{c}\text { Rentang } \\
\text { Skor }\end{array}$ & Frekuensi & $\begin{array}{c}\text { Bobot } \\
\text { Skor }\end{array}$ & $\%$ \\
\hline 1 & $\begin{array}{c}\text { Sangat } \\
\text { Baik }\end{array}$ & $90-100$ & 1 & 92 & 3,13 \\
\hline 2 & Baik & $75-89$ & 14 & 1162 & 43,75 \\
\hline 3 & Cukup & $65-74$ & 14 & 1062 & 43,75 \\
\hline 4 & Kurang & $55-64$ & 3 & 196 & 9,37 \\
\hline 5 & Sangat & $0-54$ & 0 & 0 & 0 \\
& Kurang & & & & \\
\hline \multicolumn{7}{c}{ Jumlah } & 35 & 2512 & $100 \%$ \\
\hline
\end{tabular}

Pada tahap II hasil tes pasca-aplikasi media menunjukkan hasil secara klasikal mencapai rata-rata nilai 84,63. Dari 32 siswa, ada 9 siswa $(28,12 \%)$ dengan nilai sangat baik. Ada16 siswa $(50,00 \%)$ dengan nilai baik. Ada 5 siswa $(5,63 \%)$ dengan nilai cukup. Ada 2 siswa (6,25\%) dengan nilai kurang dan 0 siswa $(0 \%)$ dengan nilai sangat kurang. Untuk memperjelas hasil tes pasca-aplikasi media tahap II dapat dipaparkan dalam tabel 3 berikut ini.

Tabel 3

Hasil Tes Pasca-aplikasi Media Tahap II

\begin{tabular}{cccccc}
\hline No. & Kategori & $\begin{array}{c}\text { Rentang } \\
\text { Skor }\end{array}$ & Frekuensi & $\begin{array}{c}\text { Bobot } \\
\text { Skor }\end{array}$ & $\%$ \\
\hline 1 & $\begin{array}{c}\text { Sangat } \\
\text { Baik }\end{array}$ & $90-100$ & 9 & 836 & 28,12 \\
\hline 2 & Baik & $75-89$ & 16 & 1356 & 50,00 \\
\hline 3 & Cukup & $65-74$ & 5 & 386 & 15,63 \\
\hline 4 & Kurang & $55-64$ & 2 & 130 & 6,25 \\
\hline 5 & Sangat & $0-54$ & 0 & 0 & 0 \\
& Kurang & & & & \\
\hline \multicolumn{7}{r}{ Jumlah } & 32 & 2708 & 100 \\
\hline
\end{tabular}

Berdasarkan tabel 1, 2, dan 3, dapat disimpulkan bahwa penggunaan media Kartu Foto Groupfie berbasis teknik Akrostik Sandi Asma ternyata mampu meningkatkan keterampilan siswa dalam menulis geguritan. Untuk memperjelas hasil tes ketiga tahap tersebut dapat dipaparkan dalam diagram 1 berikut ini.

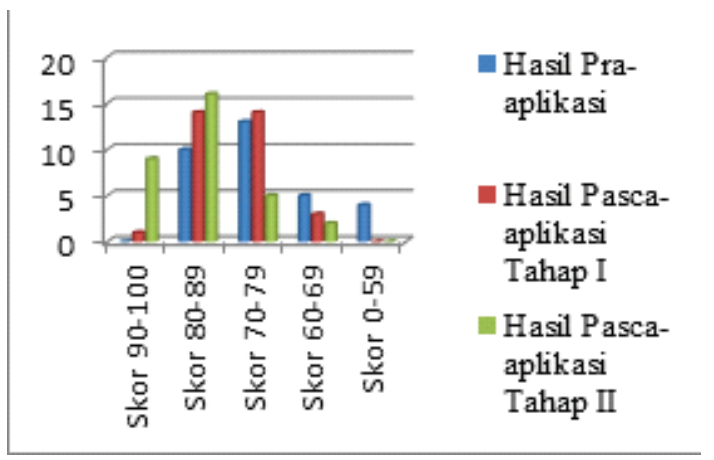

\section{Gambar 1}

Diagram1 Hasil Tes Pra-aplikasi, Pasca-aplikasi Tahap I,dan Pasca-aplikasi Tahap II 
PEDAGOGIA : Jurnal Ilmu Pendidikan

2. Peningkatan Motivasi Siswa dalam Belajar

Penggunaan media Kartu Foto Groupfie berbasis teknik Akrostik Sandi Asma terbukti memberikan dampak positif terhadap motivasi belajar siswa. Siswa menjadi lebih termotivasi dalam belajar menulis geguritan dikarenakan pe mbelajaran berlangsung menyenangkan. Selain itu, ada pengembangan karakter di antaranya (1) rasa kasih sayang kepada keluarga dan teman, (2) rasa bangga pada keluarga, dan (3) melatih mengungkapkan perasaan dengan bahasa yang indah dan santun.Penggunaan media tersebut terbukti menjadikan pembelajaran lebih menyenangkan, sehingga menimbulkan kreativitas dan keaktifan siswa.

Hasil nontes berupa observasi perilaku siswa pada pra-aplikasi media menunjukkan bahwa siswa kurang bersemangat, tiduran, dan lain sebagainya. Hasil dokumentasi kondisi awal dapat diwakili oleh gambar 2 berikut ini.

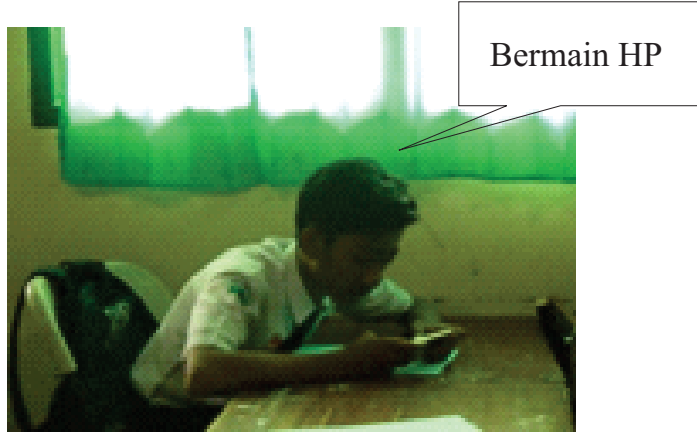

Gambar 2

Kondisi Awal

Hasil nontes pasca-aplikasi media tahap I diperoleh dari teknik observasi,catatan harian, wawancara, dan dokumentasi. Hasil observasi diperoleh data perilaku positif ditunjukkan lebih dari $80 \%$ siswa semangat dan antusias mengikuti pembelajaran, memperhatikan penjelasan guru, menanggapi media yang digunakan guru secara positif, dan mengerjakan tugas secara serius. Melalui observasi ini juga ditemukan perilaku negatif masih ada siswa yang kurang antusias dan tidak aktif dalam pembelajaran.

Berdasarkan hasil catatan harian guru diperoleh data selama proses pembelajaran berlangsung, tingkah laku siswa sebagian besar sudah menunjukkan sikap ketertiban dan respon siswa terhadap media yang digunakan, sebagian besar sangat tertarik dan antusias dalam menggunakan media. Hasil catatan harian siswa diperoleh deskripsi data bahwa rata-rata siswa merasa senang ketika mengikuti pembelajaran dengan alasanmereka mulai mampu memperoleh imajinasi dari media tersebut. Namun demikian, masih ada beberapa siswa yang menjawab kurang senang karena merasa tidak dapat menyusun kata menjadi kalimat yang akan dibuat geguritan. Selain itu, rata-rata siswa menanggapi media cukup bagus digunakan karena merupakan hal yang baru bagi mereka. Namun demikian masih ada siswa yang menanggapi bahwa media kurang efektif karena mereka tetap belum menemukan ide dan gagasan.

Wawancara kepada siswa pasca- 
PEDAGOGIA : Jurnal Ilmu Pendidikan

aplikasi tahap I ini dilaksanakan di luar jam pelajaran kepada siswa yang mendapat nilai terlampui (TL)/tercapai (TC) dan tidak tercapai (TT). Siswa yang mendapat nilai TL/TC mengemukakan berminat dengan alasan ingin terampil menulis geguritan, tetapi siswa yang mendapat nilai TT menjawab kurang berminat dengan alasan sulit menyusun kalimat dengan kata pilihan dan gaya bahasa.

Hasil dokumentasi pasca-aplikasi media tahap I meliputi pengambilan gambar (aktivitas siswa pada saat pembelajaran diwakili gambar 3 berikut ini.

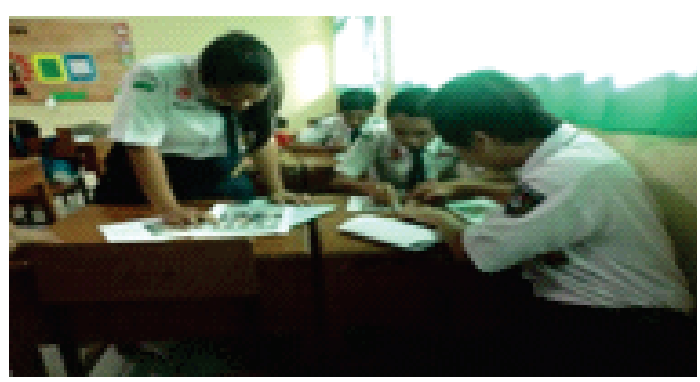

Gambar 3

Pembelajaran Pasca-aplikasi Tahap I

Hasil observasi menunjukkan $90 \%$ siswa telah menunjukkan perilaku yang positif. Adapun 10\% lainnya masih menunjukkan perilaku negatif seperti kurang semangat dalam pembelajaran dan melakukan kegiatan yang tidak ada hubungannya dengan pembelajaran, seperti mondar-mandir, bermain HP, dll.

Dari catatan harian guru selama proses pembelajaran tahap II berlangsung, diperoleh data sebagian besar siswa sudah aktif dalam mengerjakan tugas yang diberikan oleh guru. Tingkah laku siswa sebagian besar sudah menunjukkan keseriusan. Hal ini disebabkan tema yang diberikan oleh guru diganti dengan tema yang ada hubungannya dengan teman dalam satu kelas. Hal ini tentu saja menjadi sesuatu yang menarik bagi siswa karena siswa seperti diajak untuk mengenang peristiwa yang pernah terjadi di antara mereka. Ada rasa senang, sedih, konyol, lucu, haru, kecewa, semangat persaudaraan, kekompakan, dan lain-lain yang semuanya akan muncul saat siswa menlihat hasil foto groupfie bersama teman satu kelasnya. Siswa dalam pembelajaran terlihat lebih semangat, tertib, dan merespon positif siswa terhadap media digunakan guru.

Dari catatan harian siswa diperoleh data rata-rata siswa merasa senang ketika mengikuti pembelajaran dengan alasan memiliki pengalaman baru serta menarik tentang media Kartu Foto Groupfie dari teknik Akrostik Sandi Asma. Selain itu, siswa menanggapi media tersebut cukup bagus dan digunakan dapat dijadikan ajang mengekspresikan gaya

Dari wawancara pada pascaaplikasi media tahap II diperoleh hasil bahwa siswa yang mendapat nilai terlampaui/tercapai menyatakan bahwa media sangat membantu dalam merangsang imajinasi dalm menulis geguritan. Adapun siswa yang mendapat nilai tidak tercapai mengatakan kesulitan dalam menerapkan kata kiasan dalam menulis geguritan. Hasil dokumentasi 
PEDAGOGIA : Jurnal Ilmu Pendidikan

pembelajaran pasca-aplikasi media tahap II meliputi pengambilan gambar (foto) dapat diwakili gambar 4 berikut ini.

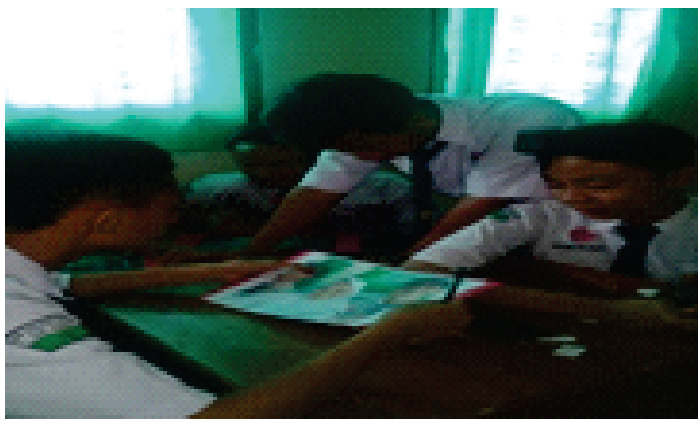

Gambar 4

Pembelajaran Pasca-aplikasi Tahap II

Berdasarkan analisis data hasil aplikasi praktis media yang telah dipaparkan dapat dibahas hal-hal berikut ini.

\section{Peningkatan Hasil Belajar Siswa}

Ketuntasan hasil tes menulis geguritan siswa pada tahap pra-aplikasi termasuk kategori tidak tuntas, karena ada 17 siswa $(53,13 \%)$ yang tidak mencapai KKM. Rendahnya hasil tersebut disebabkan oleh beberapa faktor di antaranya siswa kesulitan menerapkan kata pilihan ke dalam geguritan. Kesulitan yang dihadapi siswa ditandai dengan beberapa hal, salah satunya dalam menyusun kalimat pendek namun bermakna luas.

Setelah dilakukan tindakan pada pembelajaran pasca-aplikasi media tahap I dengan menggunakan media Kartu Foto Groupfie berbasis teknik Akrostik Sandi Asma pada pasca-aplikasi tahap I menunjukkan peningkatan dibandingkan dengan tahap pra-aplikasi media. Nilai rata-rata tes siswa pada pasca-aplikasi media tahap I sebesar 78,50 dengan distribusi siswa yang tercapai/melampui Kriteria Ketuntasan Minimal (KKM) ada 26 siswa $(81,25 \%)$. Siswa yang mencapai/melampui KKM, dan ada 6 siswa $(18,75 \%)$ yang tidak mancapai KKM.

Nilai rata-rata tes pasca-aplikasi media tahap I yang dicapai siswa belum mencapai nilai KKM sebesar 75. Hal tersebut tetap diupayakan adanya tindakan lebih lanjut pada pasca-aplikasi media tahap II untuk mencapai keberhasilan belajar siswa secara maksimal. Peningkatan hasil tes pada pasca-aplikasi media tahap II pada nilai rata-rata tes mencapai 84,63 dengan distribusi siswa yang mencapai/melampui KKMada 30 siswa $(93,75 \%)$, dan ada 2 siswa (6,25\%)yang tidak mencapai KKM. Pada pasca-aplikasi media tahap II juga mengalami peningkatan yang sangat berarti dibandingkan pada pasca-aplikasi media tahap I. Hal ini disebabkan adanya upaya perbaikan tindakan pasca-aplikasi media tahap I dengan memberikan pancingan kata untuk dikembangkan menjadi kalimat yang indah. Hal ini sejalan dengan pendapat dari Amri dan Ahmadi (2010) yang menyatakan bahwa dalam pembelajaran hubungan antara pengajar dan pembelajar dapat diwakili oleh bahan ajar atau media belajar. Pendapat tersebut diperkuat pendapat Prastowo (2012) yang menjelaskan bahwa 
pemanfaatan bahan ajar seinovatif mungkin harus disesuaikan dengan kebutuhan siswa yang akan menjadikan pembelajaran lebih menarik dan menyenangkan, sehingga menjadikan siswa dapat melalui pembelajaran semaksimal mungkin.

\section{Peningkatan Motivasi Siswa dalam Belajar}

Berdasarkan hasil observasi yang dilakukan guru pada pasca-aplikasi media tahap I dan tahap II dapat diketahui bahwa setiap tahap mengalami peningkatan. Pada pasca-aplikasi media tahap I ada 26 siswa $(81,13 \%)$ yang antusias dalam pembelajaran. Pada pasca-aplikasi media tahap II antusias dalam mengikuti pembelajaran pembelajaran meningkat menjadi 30 siswa $(93,75 \%)$. Perhatian siswa terhadap penjelasan guru pada pasca-aplikasi media tahap I siswa cukup baik. Ada27 siswa (84,34\%) yang bersemangat mendengarkan penjelasan guru. Namun demikian, masih ada siswa yang berbicara dengan teman sebangkunya di luar tema pembelajaran. Pada pasca-aplikasi tahap II jumlah siswa yang memperhatikan penjelasan guru meningkat menjadi 29 siswa $(90,63 \%)$ meskipun masih ada 3 siswa (9,37\%)yang terlihat melakukan kegiatan yang lain dalam pembelajaran, tetapi guru mampu mengkondisikan. Respon positif siswa terhadap media yang digunakan guru pada pasca-aplikasi media tahap I ada 27 siswa $(84,38 \%)$ yang tertarik dengan media yang digunakan guru. Pada pasca-aplikasi media tahap II jumlah siswa yang merespon positif meningkat menjadi 30 siswa $(93,75 \%)$. Keaktifan siswa dalam pembelajaran pada pasca-aplikasi media tahap I belum memuaskan karena hanya ada 25 siswa $(78,13 . \%)$ yang aktif. Berbeda dengan dengan pasca-aplikasi media tahap II, siswa yang aktif meningkat menjadi 30 siswa $(93,75 \%)$. Jumlah tersebut lebih banyak dibandingkan dengan pasca-aplikasi media tahap I. Keseriusan siswa saat pembelajaran pada siklus I sudah cukup baik. Ada 26 siswa (81,13\%) yang mengerjakan tugas dengan serius. Namun demikian, masih ada beberapa siswa yang copy paste dari internet. Pada pasca-aplikasi media tahap II keseriusan siswa lebih baik dibandingkan pasca-aplikasi media tahap I. Keseriusan siswa meningkat menjadi 30 siswa $(93,75 \%)$ karena masih ada 2 siswa(6,25\%) yang masih belum menyelesaikan tugasnya dengan alasan belum memiliki foto.

Berdasarkan catatan harian, siswa merasa senang dengan dengan media yang digunakan guru karena mereka dapat berselfie atau bergroupfie dengan berbagai gaya bersama keluarga atau teman dan mendapat pengalaman baru dalam menulis geguritan. Kesulitan siswa dalam menerapkan pilihan kata juga berkurang. Nilai rata-rata tes semakin meningkat dari pasca-aplikasi media tahap I ke pascaaplikasi media tahap II.

Dari hasil wawancara dapat 
PEDAGOGIA : Jurnal Ilmu Pendidikan

ditemukan simpulan bahwa siswa merespon positif terhadap media yang digunakan guru karena dapat membantu siswa merangsang imajinasi dalam menulis. Dengan bimbingan guru, siswa dapat mengatasi kesulitan yang dialami. Berdasarkan hasil nontes pasca-aplikasi media tahap I dan pasca-aplikasi media tahap II dapat disimpulkan penerapan media mampu memberikan perubahan perilaku siswa ke arah yang lebih baik. Hal ini sejalan dengan pendapat A'la (2011) yang menyatakan bahwa membuat semacam asosiasi merupakan alat bantu yang sangat luar biasa dampaknya karena hanya dibatasi imajinasi. Hasil penelitian menunjukkan bahwa mengaitkan antara informasi dengan persepsi indrawi yang kuat seperti misalnya pandangan ternyata akan membuat lebih mudah untuk terus diingat oleh otak.

\section{E. KESIMPULAN}

Berdasarkan hasil penelitian siswa memanfaatkan media Kartu Foto Groupfie berbasis teknik Akrostik Sandi Asma terbukti dapat meningkatkan keterampilan menulis geguritan. Media ini merupakan sebuah sarana untuk Membangkitkan imajinasi siswa dalam menulis geguritan dan mempermudah siswa dalam menulis geguritan.

Dampak positif penerapan media Kartu Foto Groupfie berbasis teknik Akrostik Sandi asma terhadap perilaku belajar yakni siswa mampu meningkatkan motivasi belajar siswa dan bangga terhadap nama diri sebagai wujud anugrah yang harus disyukuri sebagai salah satu penanaman nilai karakter dalam pembelajaran bahasa Jawa.

Melalui penelitian ini dapat diajukan saran guru dalam pembelajaran harus bijak dalam memilih media dengan memperhatikan karakteristik siswa. Media Kartu Foto Groupfie berbasis teknik Akrostik Sandi Asma dapat dijadikan salah satu solusi untuk meningkatkan keterampilan siswa dalam menulis geguritan.

\section{DAFTAR PUSTAKA}

A'la, Miftahul. (2011). Quantum Teaching Buku Pintar dan Praktis. Yogyakarta: Diva Press.

Amri, Sofan dan Ahmadi, Iif Khoiru. (2010). Proses Pembelajaran Inovatif dan Kreatif dalam Kelas. Metode, Landasan Teoretis Praktis dan Penerapannya. Jakarta: PT Prestasi Pustakaraya

Andrina, Y. M. (2011). Peningkatan Kemampuan Menulis Puisi dengan Media Kartu Mimpi Bergambar pada Siswa Kelas VIII SMP Negeri 8 Magelang (Doctoral dissertation).

Arsyad, Azhar. (2011). Media Pembelajaran. Jakarta: Raja Grafindo Persada.

Daryanto. (2011). Media Pembelajaran. Bandung: PT Sarana Tutorial Nurani Sejahtera. 
PEDAGOGIA : Jurnal Ilmu Pendidikan

Desmita, 2014. Psikologi Perkembangan

Peserta Didik Panduan bagi Orang

Tua dan Guru dalam Memahami

Psikologi Anak Usia SD, SMP, dan

$S M A$. Bandung: PT Remaja

Rosdakarya.

Gugun 7. (2011). Sandi Asma. Artikel. Kompasiana.

Isdisusilo. (2012). Panduan Lengkap

Menyusun Silabus dan Rencana

Pelaksanaan Pembelajaran.

Yogyakarta: Kata Pena.

Komalasari, Kokom. (2013).

Pembelajaran Kontektual Konsep

dan Aplikasi. Bandung: Refika

Aditama.

Kosasih, E. (2014). Dasar-Dasar

Menulis. Bandung: Yrama Widya.

Kurniawan, Heru dan Sutardi. (2012).

Penulisan Sastra Kreatif.

Yogyakarta: Graha Ilmu.

Mardiah, Suci. (2013). Kemampuan

Menulis Puisi dengan

Menggunakan Media Audiovisual

Siswa Kelas VII.2 SMP Adabiah

Padang. Jurnal Bunghatta.

Mujib, Fathul. (2012). Super Power in

Educating (Kegiatan Belajar-

Mengajar yang Super Efektif Tips-

Tips Menjadi Guru Super.

Yogyakarta: Diva Press.

Mulyana. (2014). Bahasa Jawa Kreatif

Panduan lengkap Menulis dan

Bahasa Jawa. Jogyakarta: Tiara Wacana.

Musfiqon, HM. (2012). Pengembangan

Media dan Sumber Pembelajaran.
Jakarta: PT. Prestasi Pustakarya.

Monika, M., Halidjah, S., \& Tirtowati, N. (2014). Peningkatan Kemampuan Menulis Puisi dengan Pemanfaatan Lingkungan sebagai Sumber Belajar di Sekolah Dasar. Jurnal Pendidikan dan Pembelajaran, 3(6).

Narwanti, Sri. (2011). Creative Learning Kiat Menjadi Guru Kreatif dan Favorit. Yogyakarta: Familia.

Prastowo, Andi.(2012).Panduan Kreatif Bahan Membuat Ajar Inovatif Menciptakan Metode Pembelajaran yang Menarik dan Menyenangkan. Yogyakarta: Diva Press.

Rahayu, P. (2015). Analisis Nilai Moral dan Estetika Geguritan dalam Majalah Panjebar Semangat Edisi September-Desember 2013. ADITYA-Pendidikan Bahasa dan Sastra Jawa, 6(3), 90-101.

Rakhmawti,I. (2015).PENGEMBANGAN MATERI AJAR MENULIS GEGURITAN UNTUK SISWA KELAS IX SMP DI KABUPATEN TEGAL (Disertasi, UNIVERSITAS NEGERI SEMARANG).

Sari, N. A. (2014). Peningkatan Kualitas Pembelajaran Menulis Puisi Dengan Metode Field Trip Pada Siswa SMP. BASASTRA, 1(3)

Sudarwati, Emi. (2015). Peningkatan Hasil Belajar Menulis Cerkak dengan Media Foto SMSHP (Selfie Media Sosial dan Hubungan Pertemanan) pada Siswa Kelas IX SMP Negeri Baureno. Penelitian 
PEDAGOGIA : Jurnal Ilmu Pendidikan

Tindakan Kelas. Dipublikasikan oleh Penerbit Dwi Putera Jaya Bojonegoro.

Sudibyo, Arief. (2008). Sekilas tentang Menulis Puisi. [Online]. http://republikpuisireeve.blogspot.c om. Diakses 13 Februari 2018. Pukul 10.35 WIB.

Sufanti, Main. (2010). Strategi Pengajaran Bahasa dan Sastra Indonesia. Surakarta: Yuma Pustaka.

Utami, Retno. (2015). Cara Asik Menulis Puisi. Bontang: Kaifa Publishing.

Utami, Sri. (2012). Peningkatan Kemampuan Menulis Puisi melalui Teknik Eks-Kalam (Eksplorasi Kata Dari Alam) di Sekolah Menengah Pertama.http://portalkurikulum.blo gspot.com/. Diakses 10 Nopember 2018. Pukul 14.35 WIB. 